UDC 81'373.45

DOI: $10.17223 / 24109266 / 11 / 3$

\title{
VASILII BELOV AND THE RUSSIAN IDEA
}

\author{
D. Gillespie, S.K. Gural, M.A. Korneeva
}

\begin{abstract}
Vasilii Ivanovich Belov (1932-2012) was one of the most wellknown and outspoken of the 'village writers' who came to prominence in the Soviet Union in the 1960s, and in the age of 'glasnost' and post-Soviet times attracted much attention and even vilification for his nationalist and apparently xenophobic views. In his documentary account of village life and customs published in the journal Nash sovremennik between 1979 and 1982, and subsequently in illustrated book form, Belov provides in great detail and with much personal warmth the history of the northern Russian village, its people, customs and way of life as it has developed over the centuries, showing a place seemingly outside of time and untouched by historical developments. Lad: ocherki o narodnoi estetike may yet prove to be his most enduring contribution to post-Soviet reflections on 'the Russian idea', and Russia's relationship with Europe.
\end{abstract}

Keywords: village prose, Russian idea, history, rural culture.

\section{Introduction}

In late Soviet and post-Soviet Russia Belov's writings on the fate of Russia in the twentieth century echo the philosophical meditations on 'the Russian idea' first articulated by Fedor Dostoevskii and Vladimir Solov'ev in the nineteenth century, and further developed by Nikolai Berdiaev in the twentieth. Although shorn of its God-building and Messianic dimensions, Belov's writings on the fate of Russia and its relationship with the West exhibit a similar sense of Russian exclusivity and its Christian 'mission'.

The writer and editor Sergei Zalygin (1913-2000) noted that the main feature of Belov's writing was his interest in the Russian villlage, and especially, 'the village least touched by modern changes' [5]. Belov's admiration of village folk for their strength and inner resilience springs from his own experience of the rural north-west of Russia, from his own observations of the life and customs of the area which was his birth-place and home. Like other 'village writers', he portrayed village life in partial and positive words and images, and injects a note of menace when urban values threaten pastoral calm. In the traditions of village prose, a constant feature of Belov's writing is the conflict between town, representing the industrial future, and village, the repository of age-old values and traditions. Nowhere is this more clearly demonstrated than in his documentary work entitled $L a d$, in which the themes of his faction published before and since are crystallized and given their clearest expression. 


\section{Analysis}

Lad was published in the journal Nash sovremennik between 1979 and 1982, and then as a fulsomely produced book published by Molodaia gvardiia in 1982. The book edition is generously illustrated with photographs and prints depicting village life in Vologda, Arkhangel'sk and Kirov districts in the Russian North. Subtitled 'essays on folk aesthetics' Lad is a documentary record of the life of the north Russian village in all its aspects, and is closer to the philosophy and gentle meditation on life seen in Privychnoe delo than in Belov's works published in the intervening years, and so it is apposite to be discussed here.

Lad is not merely a document, but also a celebration of village life. The peasant's view of the world is one where humans and animals belong to the same moral universe, where human life accords with the passage of the seasons, and where human affairs are marked by a profound natural rhythm and unity. Unlike Belov's earlier works, however, Lad examines the crafts and arts practised in the village, the trades and occupations characteristic of rural life, and the many activities and games prevalent in the village.

It begins with an account of village life in its everyday aspects from Spring through to the holidays and celebrations of Summer, when people combined work with brewing beer and visiting each other's homes, and then through to Autumn and Winter. The trades and tradesmen of the countryside, the carpenters, millers, shepherds, boot-makers, joiners, boatmen, stovemakers, even the beggars, are described in considerable detail. These were, Belov tells us, 'основные профессии, имевшие экономическое и эстетическое значение в жизни крестьянина' ${ }^{\text {. }}$ Much space is also devoted to how these trades are learned and mastered, as well as to the occupations of the village women, such as weaving and threshing flax.

Thus, we learn that the stove-maker was respected in the village community as much as the priest or the school-teacher because the stove also had a spiritual significance:

Если в духовном смысле главным местом в хоромах был красный угол главной избы, то средоточием, материальнонравственным центром, разумеется, была русская печь, никогда не остывавший семейный очаг. (49)

It helped feed, heal and comfort those of all ages. Potters and craftsmen worked 'в стремлении к божеству... не в борьбе с окружающей природой, а в содружестве с ней' (51), and thus what they created, the ar-

\footnotetext{
${ }^{1}$ Vasilii Belov, Lad: ocherki o narodnoi estetike, Moscow: Molodaia gvardiia, 1982, p. 56. All subsequent references to this work in the text are to pages in this edition.
} 
tistic image, had a spiritual quality. Artists, indeed, were distinguished by their patience, their love for their work and knowledge of the tradition in which they worked. The works they created were therefore timeless.

Hunters and fishermen likewise worked hand in hand with nature, and felt a link with the world around them:

Неподдельное и самое тесное общение с природой (вернее, не общение, а слитность которая сводит на нет ужас небытия, смерти, исчезновения), соперничество с природой, радость узнавания, риск, физическая закалка, какое-то странное самораскрытие и самоутверждение - все это и еще многое другое испытывают охотник и рыболов. (75)

Knitting, sewing, handcrafts, wickerwork, lacework, silver-engraving and wood-carving retain a spiritual quality. As acts of creativity, and to Belov the human soul becomes embodied in them. Even more mundane work, such as building a house, a bath-house, hay-making or making children's toys from clay or wood are described in detail, and is equal in importance to the making of spoons, dishes and other household utensils. Both work and art in the village typify the representation of nature in what man creates:

'Душа человеческая, через посредничество рук... вдыхает жизнь, то есть красоту, в дремлющий, но всегда готовый ожить брус гранита, дерева, или моржового клыка. (89)

The harmony and rhythm of human life are emphasised, as the times of a man's life change as naturally as the seasons of the year, an idea also expressed in his earlier works Derevnia Berdiaika (1961) and Privychnoe delo (1966). The life of the villager is recorded from childhood to old age. As he grows up and develops, the young village lad learns to fish, to make an axe, to chop wood and to get to grips with the conventions of courting. Marriage is the most important and responsible event in the villager's life: it marks the dividing-line between youth and manhood. Death holds no terror for the Russian peasant, it is merely the release from the bodily torments of old age and the moral torment of not being able to work any more. Belov depicts death as a natural and organic culmination of life, not unlike other 'village prose' writers or, indeed, Ivan Turgenev and Lev Tolstoi. As he states:

Естественная и закономерная последовательность в смене возрастных особенностей приводила к философскорелигиозному и душевнему равновесию, к спокойному восприятию конца собственного пути... Именно постеловательность, постепенность. (132) 
Although the games played by village children are described in detail, and their rationale and the joy obtained, much more important is the moral and spiritual lesson of childhood. The new-born baby is 'на грани яви и сна' (177), and the games themselves are 'серебро и золото детства' (178). In true Romantic fashion, the legacy of childhood stays with the adult throughout his life:

Долгое, очень долгое расставание с игрой у нормального человека... Только сломленный, закостеневший, не вовремя постаревший, злой или совсем утративший искру божию человек теряет потреюность в игре, в шутке, в развлечении. (184)

The customs and rituals of village life - funerals, weddings, Christmas, Christenings, match-making - are all major events, and have their own place and procedure in the life of the village. So do the festive holidays, the fairs, and the village assembly, where the elders of the village would decide questions arising from the village economy or social make-up, and where the young would spend their evenings in summer. The high points of the village calendar revolve around Orthodox festivals, such as Christmas, Shrove-tide and Easter.

Emphasised throughout the presentation of village festivals is their communal character. Similarly, family celebrations involved the whole village, even when the occasion was not a joyful one, such as a son's recruitment into the army. The sense of community spirit, the feeling of responsibility for one's neighbour, are tied up with the influence of the Church on the habits of the villagers. Thus, beggars, the blind, cripples, orphans, the poor and those in reduced circumstances, as well as soldiers recently returned from a war, would all be helped by rural folk because 'не приютить странника или нищего, не накормить проезжего издревле считалось грехом’ (46).

The unity of this world with the world of nature is accepted. The forest is a place for solitude and contemplation, the shepherd addresses animals on first-name terms, and knows the personal likes and prejudices of each of his charges, their habits, cunning tricks. Dogs, cats, cows, calves and horses have their own names:

Жизнь домашних животных никогда не противопоставлялась другой, высшей, одухотворенной жизни - человеческой. Крестьянин считал себя составной частью природы, и домашние животные были как бы соединяющим звеном от человека ко всей грозной и необъятной природе. Близость к животным, к природе смягчала холод одиночества, который томил душу человека при взгляде на далекое мерцание Млечного Пути. (147) 
The closeness to nature nurtures not only physical creativity, as outlined above, but also the peasant imagination, his ability to create a fantastical, poetic world out of the everyday. Animals could assume supernatural form, so that a cat could seem to be a domovoi at night, a wolf could become a werewolf (oboroten'), and each household would have its spirit associated with its buildings, such as the bath-house, the courtyard, the threshing-floor or the sheep-pen. These spirits could protect or cause annoyance (for example, by hiding something), and a man going away for a long period may ask the courtyard spirit (dvorushko) to protect the house in his absence. He may be answered by a rustle of the broom in the wind.

The interconnectedness of the material and the immaterial worlds is also expressed in the boundary between life and death:

считалось, что небытие после смерти то же, что небытие до рождения, что земная жизнь дана человеку как бы в награду и дополнение к чему-то главному, что заслонялось от него двумя упомянутыми тайнами. (133)

Lad continually relates the unity of man and nature, and the dependence of man's daily activity and spiritual life on the natural rhythm of the life all around him:

Почти все трудовые дела сплелись у сельского жителя с природой, а природа ритмична: одно вытекает из другого, и все неразрывно между собой. Человек всегда ощущал свое единство с природой. Это в союзе с ней он создавал сам себя и высокую красоту своей души, отраженную в культуре труда. (35)

A major section of the book is entitled 'Nachalo vsekh nachal', and is devoted to folk literature'. The word, whether spoken or written, is an expression of the 'стремление к прекрасному' (197), the aesthetic ideal. Belov asserts that folk literature, through the various genres of predanie, byval'shchina, skazka, bukhtina, and song and music have their own moral code. Like the everyday round of the peasant, his culture combines reality with the fantastic. The predanie is dependent on the ability to exaggerate actual events, the byval'shchina relies on the clash of the real and the fantastic, the skazka mingles truth with the unlikely in such a way that the listener is unsure whether to believe it or simply laugh, and the bukhtina is a joke or

\footnotetext{
${ }^{1}$ Another sub-heading, 'Ne khlebom edinym', is included in the original journal publication (Nash sovremennik, 1980, no. 3) but is missing from the book edition, presumably because of its explicit Biblical association.
} 
anecdote that subverts common sense. In this culture the fantastic element in essentially humorous, absurd or irrational ${ }^{1}$.

Songs, accorded much importance in the spiritual life of the peasant in Belov's earlier work, symbolize the peasant's innate feeling for music. Poets could write verses on any amusing topic to the rhythm of a chastushka. Music was inspired by the natural and rhythmical sounds of the surrounding countryside, the forest and the river. Water splashing in a storm arouses trepidation in a man's soul, as does the wind at night which prevents him from наличие зрителяаnd man's music binds him to this world:

Слияние естественных природных шумов и звуков с искусственно-музыкальными вызывает ощущение волшебства... Печальный и нежный голос пастушьего рожка так необходимо-естественен среди этих теплых лесов! Он ведет свою мелодию, и она, словно тонкая нить, связывает безьрежность мира с душой человека. (255)

The art and culture of the way of life described in Lad is seen as an organic part of that life, and the artistic image is thus the "родное дитя традиции, оплодотворенной вдохновением художника' (286). The image is born of rhythm and a natural symmetry. Belov sees the sublime qualities of art that embodies the truth of life in direct contrast to the consumer art of $\mathrm{TV}$, film and the radio today:

По глубокому убеждению автора, в наше время сформировался «полупроводниковый» характер культуры, когда радио, телевидение, кино, концерты вырабатывают потребительское отношение к культуре, а сама культура напоминает улицу с односторонним движением. Люди разделены на две части: одни на сцене поют и пляшкт (создатели), другие внизу смотрят и слушают (потребители). Художественная самодеятельность, в которой бы участвовали все без исключения, в клубных условиях невозможна. Хотя бы по той причине, что любая эстрада, любая сцена подразумевает наличия зрителя, так сказать, потребителя. В этом принципиальная разница между художественной самодеятельностью и такими явлениями, как старинная свадьба или ны-

\footnotetext{
${ }^{1}$ Belov's use of folklore in the structure and characterization in his works has been discussed in two excellent articles by T. Krivoshchapova: 'Rol' prozaicheskikh fol'klornykh zhanrov v tvorchestve Vasiliia Belova', Vestnik moskovskogo universiteta, 10 (Filologiia), 4 (1976), 3344, and 'Skaz i rasskazchik v proze V. Belova', in D. N. Medrish (ed.), Problemy iazyka $i$ stilia v literature, Volgogradskii gosudarstvennyi pedagogicheskii institut, 1978, pp. 94-101.
} 
нешняя горка на Усть-Цильме, в которых участвуют все и где нет разделения на артистов и зрителей. $(290 \text { (n.) })^{1}$

The rhythm and unity of the Russian village, of man and nature, are lost in the modern world which Belov judges in extremely negative terms. The city represents the loss of innocence and spiritual richness, and his idyllic picture of life in the village is directly expressed in this extended quotation from the book's introduction (which could also serve as its conclusion):

Ритм - одно из условий жизни. И жизнь моих предков, северных русских крестьян, в основе своей и в частностях была ритмичной. Любое нарушение этого ритма - война, мор, неурожай - лихорадило весь народ, все государство. Перебои в ритме семейной жизни (болезнь или преждевременная смерть, пожар, супружеская измена, развод, кража, арест члена семьи, гибель коня, рекруство) не только разрушали семью, но сказывались на жизнь и всей деревни.

Ритм проявлялся во всем, формируя цикличность. Можно говорить о дневном цикле и о недельном, для отдельного человека и для целой семьи, о летнем или о весеннем цикле, о годовом, неконец, о всей жизни: от зачатья до могильной травы...

Все было взаимосвязано, и ничто не могло жить отдельно или друг без друга, всему предназначалось свое место и время. Ничто не могло существовать вне целого или появиться вне очереди. При этом единство и цельность вовсе не противоречили красоте и многообразию. Красоту нельзя было отделить от пользы, пользу - от красоты. Мастер назывался художником, художник - мастером. Иными словами, красота находилась в растворенном, а не кристаллическом, как теперь, состоянии. (7)

\section{Conclusion}

Belov's idealization of the village and the past, as expressed in his work of the 1960s and 1970s, spills over into a nationalistic fervour bordering on xenophobia in the more liberal times of the 1980s and 1990s, where the 'rhythm' and unity nurtured and developed in the village are markedly

\footnotetext{
${ }^{1}$ Belov's conservative, not to say reactionary, views on popular art and the media have found expression elsewhere, and will be discussed later in relation to his works on urban life. For instance, in 1980 he railed against 'халтура и циничный вкус' in film and the theatre, where nudity is 'чуть ли не норма'. This, as well as TV, is to him 'not art'. See 'Da polnote, iskusstvo li vse eto?', Komsomol'skaia pravda, 4 July 1980, p. 2.
} 
absent in stories about urban life, and where the incursion of rationalist ideas in the form of dekulakization and collectivization of agriculture destroy the spiritual and cultural foundations of the Russian village.

\section{References}

1. Belov, V.: Lad: ocherki o narodnoi estetike, Nash sovremennik [Mood: essays on folk aesthetics, Our contemporary] (1979:10), 117-158, (1979:12), 85-96, (1980:3), 60-84, (1981:1), 160-74, (1981:5), 145-171, (1981: 6), 143-153, (1981:7), 125-164. Moscow: Molodaia gvardiia (1982)

2. Belov, V.: Da polnote, iskusstvo li vse eto? [C'mon, is it all art?], Komsomol'skaia pravda, p. 2 (1980)

3. Krivoshchapova, T.: Rol' prozaicheskikh fol'klornykh zhanrov v tvorchestve Vasiliia Belova [The role of prose folklore genres in the oeuvre of Vasily Belov], Vestnik moskovskogo universiteta, 10 (Filologiia), 4, pp. 33-44 (1976)

4. Krivoshchapova, T.: Skaz i rasskazchik v proze V. Belova [The tale and narrator in the prose of Vasily Belov], in D.N. Medrish (ed.), Problemy iazyka i stilia v literature, Volgogradskii gosudarstvennyi pedagogicheskii institut, pp. 94-101 (1978)

5. Zalygin, S.: Posleslovie [Afterword], in Vasilii Belov's Sel'skie povesti, Moscow, Khudozhestvennaia literatura, pp. 331-334 (1971)

Information about the authors:

Gilltspie D. - Professor, University of Bath, UK (Bath, UK). E-mail: E-mail: gural.svetlana@mail.ru

Gural S.K. - D.Sc. (Education), Professor of the Department of English Philology, Tomsk State University (Tomsk, Russia). E-mail: gural.svetlana@mail.ru

Korneeva M.A. - Ph.D., Senior Lecturer, Department of the English Language of Natural Science and Physics and Mathematics Faculties of National Research Tomsk State University (Tomsk, Russia). E-mail: active_eng@mail.ru

Received 21 April 2018 